\title{
BRD4/NUTM1 Fusion Gene
}

National Cancer Institute

\section{Source}

National Cancer Institute. BRD4/NUTM1 Fusion Gene. NCI Thesaurus. Code C99831.

A fusion gene ( $6 \mathrm{~kb})$ that results from a chromosomal translocation $\mathrm{t}(15 ; 19)(\mathrm{q} 14 ; \mathrm{p} 13)$ which fuses the first 10 exons of the BRD4 gene with exon 2 of the NUTM1 gene. This rearrangement is associated with a rare, aggressive, and lethal carcinoma arising in midline organs of young people. 